\title{
Determination of Geological Linear Structures of the Low Beskids - Assessment of Suitability of Landsat 8 Satellite Images and Products of the Image Processing**
}

\section{Introduction}

Interpretation of satellite images is one of the methods used in geological studies. Accessibility and the relatively small cost of images has led to remote-sensing methods becoming one of the basic tools for analysing and displaying: the identification of rocks and soils, geological structures, mineral resources, oil, geothermal waters, the monitoring of geological phenomena and the identification of the form of the terrain. After several decades of use, the consensus among experts is that the basic benefit of using remote-sensing materials services in geology is the possibility to obtain information with regard to tectonics $[1,7,11]$. Robert Helbling is the founding-father of photogeology and in the 1930s, in the Alpine massif, he conducted studies concerning cartography and geology, photointerpretation and photogrammetric. These studies can be applied to larger areas through the use of the same methods and research parameters and enable the use of greater accuracy as well as cost reduction and the acceleration of studies [5]. It has been confirmed by current geological studies [11, 25]. The advantage of graphic material is strict dating and the possibility of repeated studies by means of various criteria and methods. It also allows for easy repetition of studies at different times, as well as the monitoring of changes. The possibility of the complementary use of the photogeology is particularly important, through the use of modern methods of aerial and satellite geophysics, the observation of magnetic and radiometric images, cartographic references, the digital terrain model and the implementation of further geological works in selected regions without the examination of the entire area [4, 11, 22].

The main factor for the surface of the area which may be noted using remote-sensing methods is lineaments. This ambiguous term was introduced to the geological literature at the beginning of the 1930s by Hobbs, though it was examined

\footnotetext{
* AGH University of Science and Technology, Faculty of Mining Surveying and Environmental Engineering, Krakow, Poland

** This article has been prepared within the scope of the AGH UST statutory research no. 11.11.150.949
} 
earlier, in 1879 by Kjerulf who was the pioneer in this field [11]). The ambiguity of this concept encouraged experts to discuss the standardization of the term "lineaments", among others, [6, 9]. In Poland [4, 23] the definition of lineaments given by O'Leary was proven to be right [20]: Linear surface features (or the composition of the surface) which differ distinctly from the patterns and presumably reflect subsurface phenomena.

The problem of geological lineaments is described in detail in many publications [11-13, 15, 16, 19, 20, 23, 24, 26]. Unfortunately, it has not brought a universal consensus, and in addition it makes an impression that such a solution is impossible to be achieved because of the presence of linear features or their groups stem from many reasons, each of them affecting the course of lineaments in various areas. In addition, various lineaments may refer to one area, depending on the type of image, parameters, the methods of interpretation and a subjective assessment by the researcher. Lineaments which do not obtain clear explanation are still described [15]. Currently, more than a hundred years after the idea was first discussed [13], opinions prevail that there is a relationship between the course of the linear features of terrain and areas or lines of lineaments [16]; even the term linear tectonics was created to this end [24]. Thanks to the geological interpretation, among others, of Landsat and Meteor satellite was observed that Carpathian Mountains are crossed with lineaments. These lineaments correlate in certain sections and sometimes in greater areas with known fault zones [19]. In some cases, this correlation tends to be direct, especially in cases where the land is not covered with vegetation. Here the course of the lineaments is usually identical with the intersection line of fault zone, including excessive gaps with a large density of cracks. However, when these formations are covered with loose material it is the main indicator in finding intermediate premises of non-continuous base surface [27]. Intermediate features include the structure of the terrain, soil coverage and natural detritus, the location of flora and ground waters. It is believed that deeper disjunctions appear as a result of their young origin [26]. Despite the compliance of various authors in the aforementioned problems, the background of structurally specific lineaments in the covered areas is unknown and the projection mechanism of such features the depth and surface as well as the depth at which this projection occurs. From the above thesis, it stems that the shorter the lineaments are, the more complex their interpretation is. Controversies concerning the relationships between the course of the lineaments and geological structure of a given area do not change the existence of linear forms in aerial, satellite and radar photos as well as on topographical maps. The problem constitutes the proper interpretation of these forms [15].

The first attempt to summarize satellite images for the interpretation of the lineaments of Poland was presented in the Photogeological Map of Poland at a scale of 1:1 000000 [2]. The map was prepared on the basis of several Landsat MSS and HCCM satellite images. Another, more precise photolineament map of Poland was prepared at a scale of 1:500 000 [8]. Regardless, interpretative works were conducted 
on a greater scale only in selected areas of Poland $[3,25]$, including the use of new data sources related to microwaves [12]. The updated lineaments' map of Poland has not been re-examined since the $80 \mathrm{~s}$, despite the fact that in that time, the periodic development of satellite systems and remote-sensing methods related to processing images took place. There was no elaboration of the area of the Low Beskids. This publication raises an attempt to assess if, and if it is correct, which of the selected computer techniques for strengthening the image make it possible to obtain the greatest number of correct lineaments assigned; more precisely and realistically, detecting their progress in comparison to works implemented for this area during the 80s. In summary, the primary objective of the research is to make a two-step validation of the various methods of image strengthening for geological interpretation (lineaments). The first phase, reported in this publication, covers the feasible procedures using a standard set of 6-channel Landsat mission. The second step is to take into account the new opportunities linked to increased radiometric and spectral resolution of Landsat 8 . Such a comprehensive validation of remote sensing methods implemented for the most popular civilian imaging system has not been carried out yet. The published analysis takes into account the usefulness of different data sets, relying mainly on interpretation of colour compositions [8, 10, 11, 12, 25]. The attempt undertaken ranks various methods of strengthening the content of satellite images based on proprietary, binding quantitative and qualitative indicators of image interpreter work opportunities.

\section{Methodology}

\subsection{Research Area}

The standard accepted area is the Low Beskids, part of the Middle Beskids which runs on both sides of the European watershed and close to the Slovak border. It leads from the Tylicz Pass along with the Kamienica River in the west up to Łupkowska Pass and the Valley of Osława River in the east.

The Low Beskids consists of many relatively short mountain ridges and leads NW to SE. These ridges connect in two clear routes which are divided by a range of small mountainous valleys. The structure of the terrain shows strict correlation between rock resistance and the course of tectonic structures. Mountain ridges are built from Magura sandstone which is more resistant to weathering and their course direction is established as predominantly similar to folds and shells. The study area is dominated by wide and rounded ridges and tops with upper areas which are 50-100 m wide. Peaks culminate at $500 \mathrm{~m}$ and $760 \mathrm{~m}$ above the sea level, and the highest hill in the eastern part is the Piotruś mountain $(716 \mathrm{~m})$, while in the western part it is the Baranie mountain $(754 \mathrm{~m})$. Short side valleys are divided mostly by narrow and rounded ridges and tops. Slopes of ridges and slopes of valleys are most often convex and concave less frequently straight or in convex [17]. The operation 
area covers two main tectonic elements. These are Magura unit in the south and Dukla unit. Magura, in the scope of studies, is represented by the geological formations which are part of the front side of Racza zone (Gorlice). In the area of the Low Beskids between Zdynia and Komańcza in the south of Jasło, only the north Racza zone is assigned [18].

Taking into consideration the interpretation of satellite images, the region is presented as disordered, considering the terrain structure. The diversity of the image's photomorphic qualities refers in general to the lithological and tectonic changes. The terrain structure partially refers to lithology and tectonics. Areas which have a deeper aquifer storage level are situated in the north which corresponds to the terrain and tectonics [21]. In terms of the ability to detect lineaments, the test area constitutes deliberate compromise between the lowland and mountainous areas. The mountains are the only areas where geological structures are not hidden under a thick layer of quaternary formations that effectively prevent the location of the smaller forms from the satellite. Additional support for the interpreter in such areas, is shading associated with the lighting of the terrain (the course of the ridges and valley bottoms) or compact wooded areas related to the shape of the terrain. Thus masking the nature of the vegetation cover, or the impact of topography, and hindering a lot of photointerpretation work (in the case of searching for lineaments it occurs to a limited extent), often even constituting an asset to data. This can be spotted easily when analysing the lineament maps of Poland, where in far fewer of the lowland areas have been determined compared to the mountainous areas $[2,3,8,10]$.

\subsection{Data}

The accepted level of detail for the compilation was 1: 200 000. It is higher than for the previously made lineament maps for the Low Beskids and conforms to the scale of the current geological maps constituting verification material. At this level of detail, the usage of data of Landsat 8 mission is the optimal solution (appropriate spatial resolution, no-cost, easy availability, improved performance in terms of recording compared to earlier missions). The analytical work was carried out in 2014, hence the choice of data (from a new imaging system) was limited.

The main material for the analysis was the scene of June $13^{\text {th }}, 2013$, characterised by high contrast, lack of clouds, and the minimized effect of topography impact. Extra additional scenes were from 29.09.2014 and 03.21.2014. Due to the repetitive hours of morning recording, the effect of topography on the lighting of objects had a similar geometrical course, differing mainly in intensity. The main advantage of using multitemporal images was the facilitated interpretation of vegetation, primarily differentiation in types of forests. The use of such a complementary data set provided validation results with the basic representativeness criteria in relation to the Landsat 8 data.

The data was geometrically calibrated on the basis of orthophotomaps coordinates from aerial photos which are available on a WMS server (Geoportal). 


\subsection{Image Processing}

Multi-variety image processing was conducted. It can be divided into two groups: strengthening the reflection on a single channel and/or panchromatic channel and strengthening of the multispectral image content. Preliminary tests, during which the available channels or sets were subjected to individual procedures, made it possible to indicate the nine potentially most useful results in order to implement detailed interpretative works which are: the panchromatic channel with strengthened contrast, the thermal channel with strengthened contrast, the threshold result of the image, the threshold result quantization results of the near infrared channel; the high pass filtration results (Sobel's filter) of the near infrared channel, the composition in natural colours (KB 123), KB 234, KB 247, and an additional coloured composition based on inter-channel weighting (KB 2/4, 2/5, 3/5). Channel numbering was used according to Landsat 5 and 7.

\subsection{Determination of Lineaments}

The course of lineaments was set out on prepared materials, independent for each dataset, without support from additional materials. According to the "top-down" method the first stage included images reviewed in terms of probable location and linear features. Such areas are characterized by a sudden change of tone, image or other features which may indirectly point out the location of the lineaments. Then areas on the image are selected which, apart from tonal differences, are linear in geometry. Areas of anthropogenic origin, e.g. higher class road, railway routes etc., are excluded from the previously selected areas (Fig. 1a). The next stage is marking out of the exact course of lineaments in a given area. In a larger scale, within the previously marked location, the lineaments are determined via the use of rules for geological photointerpretation. The last step is vectoring (Fig. 1b).

a)

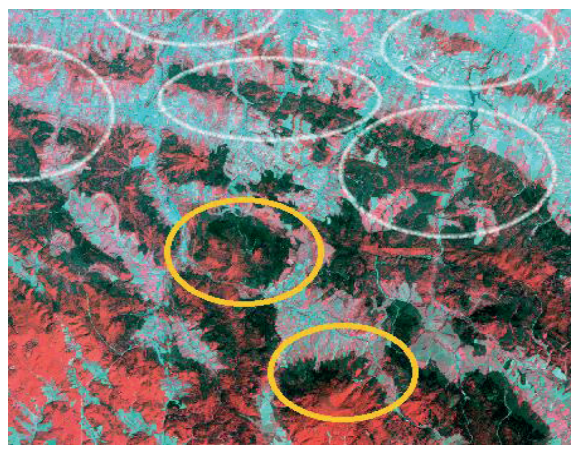

b)

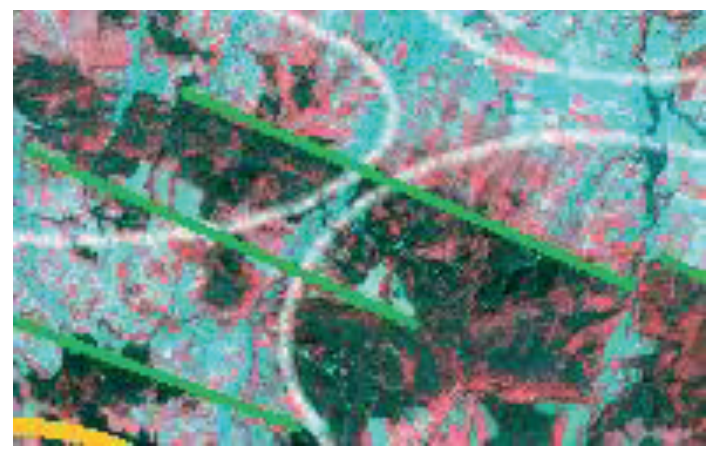

Fig. 1. Lineaments' setting process:

a) initial selection of potential occurrences (yellow indications suggest tonal differences which do not indicate linear features of the terrain; white - areas where is the possibility to draw in the lineaments); b) set lineaments (green colour) 


\section{Results}

\subsection{Assessment Criteria}

The lineaments, obtained through interpretations of the underlays of various images, were compared (Fig. 2). When working on scenes from three terms, the image registered in June constituted the basis, while observations made on the other data sets were only verified. Additionally, the use of images from March and September allowed for researchers to follow the morphology of the terrain, associated with a lower position of the sun. Early-spring images also facilitated the detection of linear demarcations of different types of forest. The results (Tab. 1) are compared due to the objective numeric features (i.e. per number of linear features which are designated on a given area, their total and average length), and subjective characteristics such as ease of interpretation and location precision (possibility of clear interpretation of the course of the characteristic), on a scale from 0 - for the smallest to 10 - for the greatest.

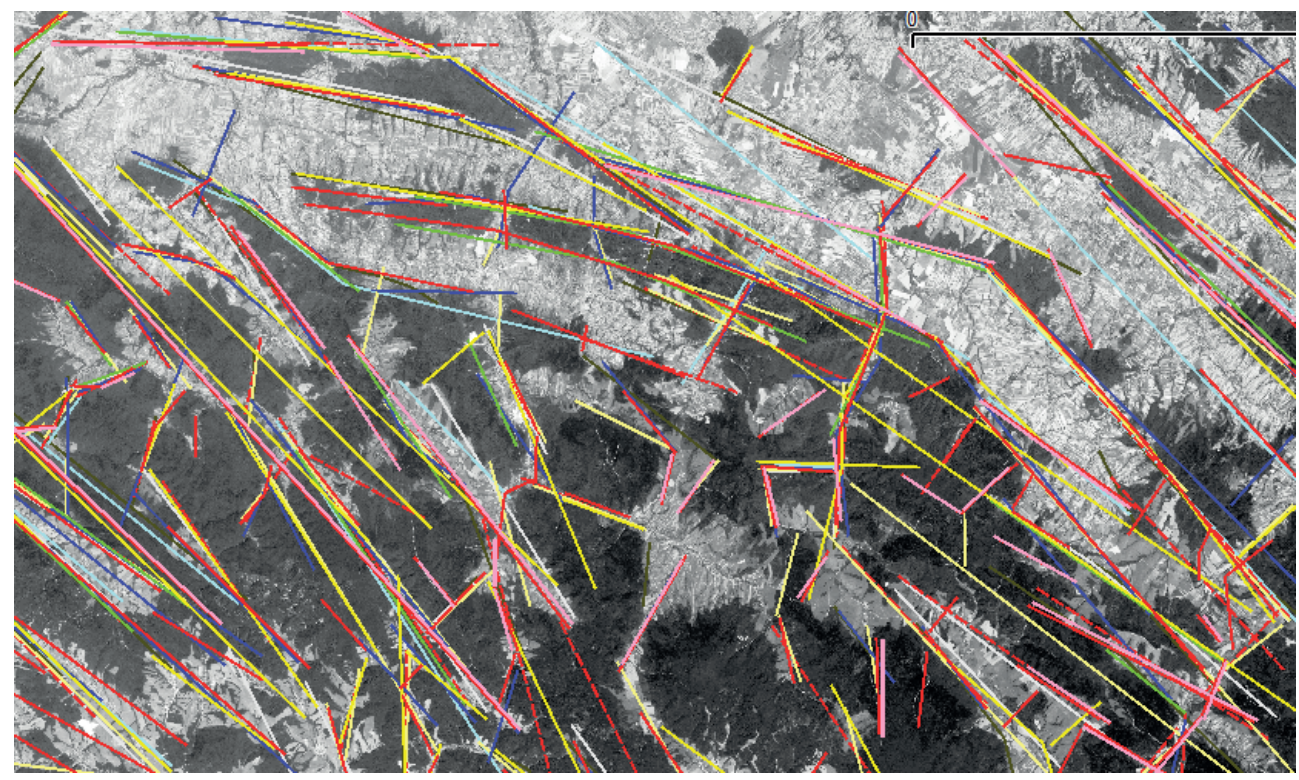

Fig. 2. Full set of the lineaments which were designated as a result of geological photointerpretation. Red colour - inter-channel weightingm, white - KB 234, violet - KB 247, maroon - KB 123, yellow - quantization, brown - panchromatic image, grey - thresholds, green - filtration, light blue - thermal channel

The lineament length illustrates the extent of a given phenomenon, e.g. the length of the overlap, and the amount can show a lot of geological curiosities spread across the space. Whether a given phenomenon has a greater or lesser length is not of critical importance, since lineaments have a secondary form when creating a geological map 
(they only suggest the possibility of changes in the geological stratum) and are subject to verification in the field (the confirmed phenomenon is then described in detail). Therefore, the most important parameter adopted was the number of possible assignations in a given data set, and treating the list of lineament lengths secondarily, as characterising the level of detail of assignations obtained in the given method.

Weights are established in order to obtain a synthetic image for different methods: 0.1 for the number of assignations and 0.45 for the ease of interpretation and location precision. The results were counted according to the obtained synthetic evaluation and the initial use of different methods was set.

Table 1. Comparison of the satellite image processing methods in order to set the lineaments

\begin{tabular}{|c|l|c|c|c|c|c|c||}
\hline No. & \multicolumn{1}{|c|}{ Set data } & $\begin{array}{c}\text { The } \\
\text { number of } \\
\text { lineaments }\end{array}$ & $\begin{array}{c}\text { Total } \\
\text { length } \\
{[\mathrm{km}]}\end{array}$ & $\begin{array}{c}\text { Average } \\
\text { length } \\
{[\mathrm{km}]}\end{array}$ & $\begin{array}{c}\text { The ease of } \\
\text { interpretation }\end{array}$ & $\begin{array}{c}\text { Location } \\
\text { precision }\end{array}$ & $\begin{array}{c}\text { Synthetic } \\
\text { evaluation }\end{array}$ \\
\hline \hline 1 & 113 & 712 & 6.3 & 10 & 9 & 20 \\
\hline 2 & $\begin{array}{l}\text { Inter-channel } \\
\text { weighting }\end{array}$ & 73 & 482 & 6.6 & 10 & 10 & 16 \\
\hline 3 & KB 234 247 & 58 & 452 & 7.8 & 9 & 10 & 14 \\
\hline 4 & KB 123 & 52 & 432 & 8.3 & 7 & 5 & 11 \\
\hline 5 & Quantization & 44 & 510 & 11.6 & 6 & 6 & 10 \\
\hline 6 & PAN image & 46 & 386 & 8.4 & 5 & 4 & 9 \\
\hline 7 & Thresholds & 35 & 368 & 10.5 & 4 & 3 & 6 \\
\hline 8 & Sobel's filter & 19 & 205 & 10.8 & 2 & 2 & 4 \\
\hline 9 & Thermal channel & 19 & 270 & 14.2 & 0 & 1 & 2 \\
\hline
\end{tabular}

An additional comparison was conducted in relation to the repeatability of the assigned lineaments in the particular methods. It turned out that these methods even those which occupied further positions in the evaluation - make it possible to determine new linear facilities, other than better methods. For instance, assuming the base result which was obtained through the inter-channel weighting, thanks to further methods as compared to the 113 recognized lineaments, the following amounts of new quantities were recognized (sequence in accordance with the method's location the in Table 1, starting from the position No. 2): 9, 11, 9, 4, 9, 4, 2, 4.

\subsection{Verification of Results}

The verification process checked to what extent set lineaments are consistent with linear features and geological structures. The results were compared with: a geological map of Poland at a scale of 1:500 000 (which was available on the WMS server (Geoportal)), with a similar photolineament map of Poland at a scale of $1: 500000$ (which was made available for the purposes of the present paper by the Cracow branch of the Polish Geological Institute [8]) and the latest geological map of the Carpathians at a scale of 1: 200000 (which was prepared by an international team of geologists from Poland, Slovakia and Ukraine and loaned by one of the authors [14]). 
The map on the WMS server is mostly generalized and applies only to the territory of Poland. However, on the basis of this material it was observed that the course of most of the lineaments logically correspond with geological structure. More comparative information was also delivered (the map of a Bordering Area) [8]. The map was scanned and calibrated, which made it possible to map previously designated lineaments. It may be concluded that most of the detected lineaments are consistent with the previous lineaments. In addition, more lineaments were drawn in as compared to previous research. Further, detailed statistics were not conducted due to the low accuracy of the verification material.

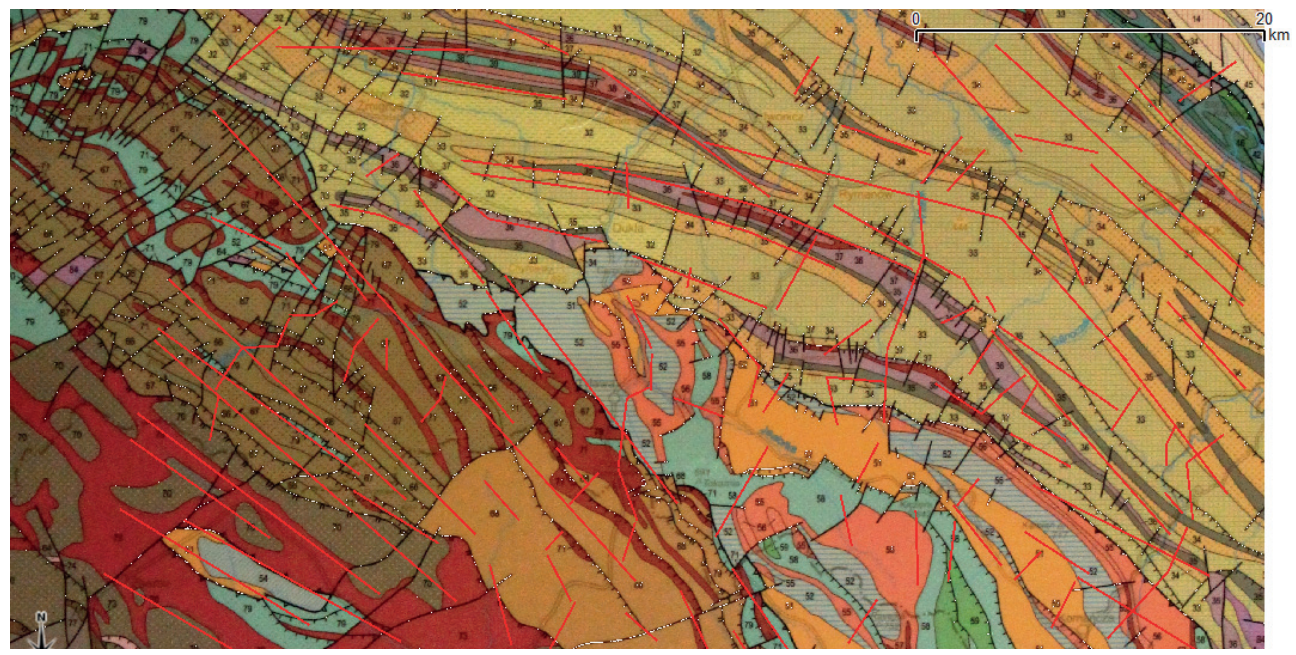

Fig. 3. The result obtained at coloured composition which was based on inter-channel weighting on the basis of the geological map of Carpathians at a scale of 1: 200000

A detailed analysis of the study's results was conducted with the use of the geological map of the Carpathians at a scale of 1: 200000 (Fig. 3), which was issued by the Polish Geological Institute in 2004. It is the latest and most detailed geological map which is available for this region. Researchers seek compliance, of course, of the linear features of the terrain with, usually reflected, discontinuity zones, geological boundaries or fold axes. A division was made between the lineaments which; are fully reflected in geological structure, are partially reflected or not reflected at all (Fig. 4, Tab. 2).

The original indicator for the lineament assignation methods was established (1), which is connected with the number of particular assignations in three lineaments groups. The indicator, thanks to its structure, describes the potential of the information data set in a given processing method to determine lineaments of good quality (Tab. 2):

$$
W_{\text {suitability }}=\left(L_{\text {geological mirroring }}^{2} \cdot L_{\text {part of geological mirroring }} \cdot L_{\text {without geological mirroring }}{ }^{-1}\right)^{0.5}
$$


a)

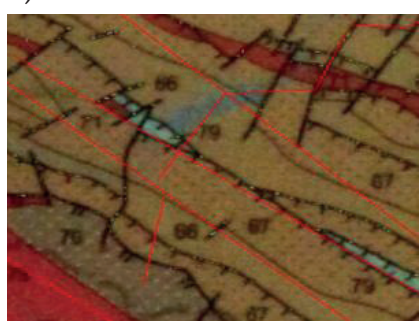

b)

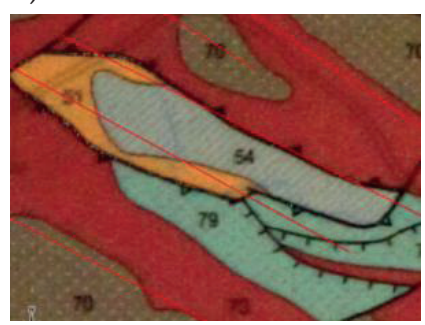

c)

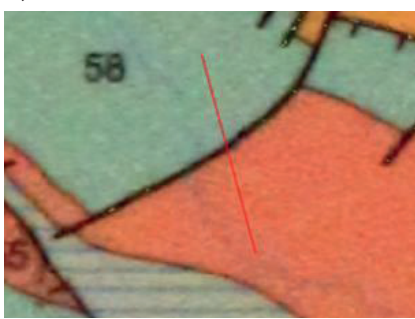

Fig. 4. An example of the division of the lineaments which were designated based on the geological map of Carpathians:

a) the lineaments overlap with elements of tectonics; b) partially with boundaries geologic;

c) the lineaments which are not reflected in geological knowledge

Table 2. Verification of determined lineaments

\begin{tabular}{|c|c|c|c|c|c|c|c|c|}
\hline \multirow{2}{*}{ No. } & \multirow{2}{*}{ Set data } & \multicolumn{2}{|c|}{$L_{\text {geological mirroring }}$} & \multicolumn{2}{|c|}{$L_{\text {part of geological mirroring }}$} & \multicolumn{2}{|c|}{$L_{\text {without geological mirroring }}$} & \multirow{2}{*}{$W_{\text {suitability }}$} \\
\hline & & quantity & {$[\%]$} & quantity & {$[\%]$} & quantity & {$[\%]$} & \\
\hline 1 & Inter-channel weighting & 49 & 43 & 39 & 35 & 25 & 22 & 61.2 \\
\hline 2 & KB 234 & 25 & 35 & 25 & 33 & 23 & 32 & 26.1 \\
\hline 3 & KB 247 & 20 & 34 & 22 & 38 & 16 & 28 & 23.5 \\
\hline 4 & KB 123 & 17 & 33 & 14 & 27 & 21 & 39 & 13.9 \\
\hline 5 & Quantization & 16 & 36 & 19 & 43 & 9 & 20 & 23.2 \\
\hline 6 & PAN image & 19 & 42 & 11 & 22 & 16 & 36 & 15.8 \\
\hline 7 & Thresholds & 15 & 45 & 7 & 18 & 13 & 36 & 10.9 \\
\hline 8 & Sobel's filter & 11 & 58 & 4 & 21 & 4 & 21 & 11.0 \\
\hline 9 & Thermal channel & 7 & 37 & 8 & 42 & 4 & 21 & 9.9 \\
\hline
\end{tabular}

\section{Discussion of Results}

The comparison of the methods which are presented in Table 1 indicates three subgroups which differ in terms of the number of assignations. The first group, which is the weakest, focuses on the work at the thermal channel, boundary filtration and thresholds' results. The second group of methods focuses on the work on the panchromatic image, coloured composition in natural colours and quantization results. The third group focuses on 234 and 247 coloured composition which is based on inter-channel weighting. 
The reason for the low suitability of the thermal channel may result from significant forestation of the study area (the image shows the radiation temperature of forests, and not soils and outcrops of rock) and pixel size $(100 \mathrm{~m})$. The results do not confirm thermal image suitability which was reported in the paper [25]. The images after applying filtering and thresholding do not constitute good material for interpreting due to the significant image simplification, which causes the disappearance of numerous intermediate interpretive features (e.g. shadows). The "Raw" panchromatic image despite good resolution $(15 \mathrm{~m})$, poorly differentiates shadows and discontinuity borders. The quantization, which was made on infrared channel, presents a relatively good image (NIR). It is confirmed by the fact that most information about tectonics and lithology are contained in close and medium infrared channels.

An important indicator which improves interpretation qualities is the work on coloured images and not on binary or gray images. The simplest composition in natural colours gave approximately $20 \%$ better quantifiable results than the results of the panchromatic channel, in spite of its better spatial resolution. KB 247, dedicated for geological surveys and KB 234 proved highly satisfactory in their interpretation of the lineaments. Plenty of linear objects assignations were observed particularly in the case of the last one. The best surveyed composition is the one which was made through inter-channel weighting. It gives approximately $100 \%$ better results than the worst method and approximately $25 \%$ better than the second best. The method of channel division and formation coloured compositions enables us to locate the greatest number of linear elements of the surface via the analysis of various indirect and direct features of the image. This composition emphasizes the interpretative features which are necessary for geological interpretation. The key to good results is the use of infrared channels, especially the fourth and fifth channel. These channels reinforce the mapping of vegetation, which in the research area - besides the shape of the terrain - is a key indicator of lineaments.

Verification through comparison of determined lineaments with valid geological knowledge (Tab. 2), does not change significantly from the sequence of methods specified in Table 1. The high suitability of inter-channel weighting was confirmed. Three subsequent methods, which are based on coloured compositions (particularly on the KB 123), proved worse.

Beneficial proportions in the number of correct assignations were recorded for quantization, which, thanks to the relatively large number of assignations, levelled its suitability with the KB 234 and KB 247 and made it possible to overtake the KB 123 and panchromatic image. The method based on filtration obtained a good proportion of correct assignations. However, due to the very small number of the detected lineaments, the method cannot be considered as useful.

To sum up in both stages of selecting the processing methods, it should be emphasized that the image material obtained as a result of inter-channel weighing made it possible to determine more lineaments than in other cases which correspond to a significant extent in geological knowledge. Other data sets do not indicate 
the location of as many linear features. Particularly, simple operations which are performed on single images indicated linear features of great length which illustrate the clear boundaries of geological zones and huge faults without due regard to smaller forms. This can be confirmed quantitatively using an average lineament length parameter omitted during validation (Tab. 1). Quantization deviates partly from this relationship, where at relatively large amounts of detected lineaments, still maintained is a high average length of an object. As a result, thanks to this method, a high total length of assignations can be achieved (second place).

Figure 5 shows lineaments which were not drawn in earlier, which are noted in this survey. New linear characteristics of the surface were drawn in thanks to the application of significantly better imaging data and methods of their processing than in the work on the photolineaments map of Poland from 1988 [8]. Lineaments which are not reflected in the structure may result from their anthropogenic nature or interpretation errors. If it is possible to exclude the above reasons, as it can be expected that any geological boundaries or tectonic zones should be located in the indicated places.

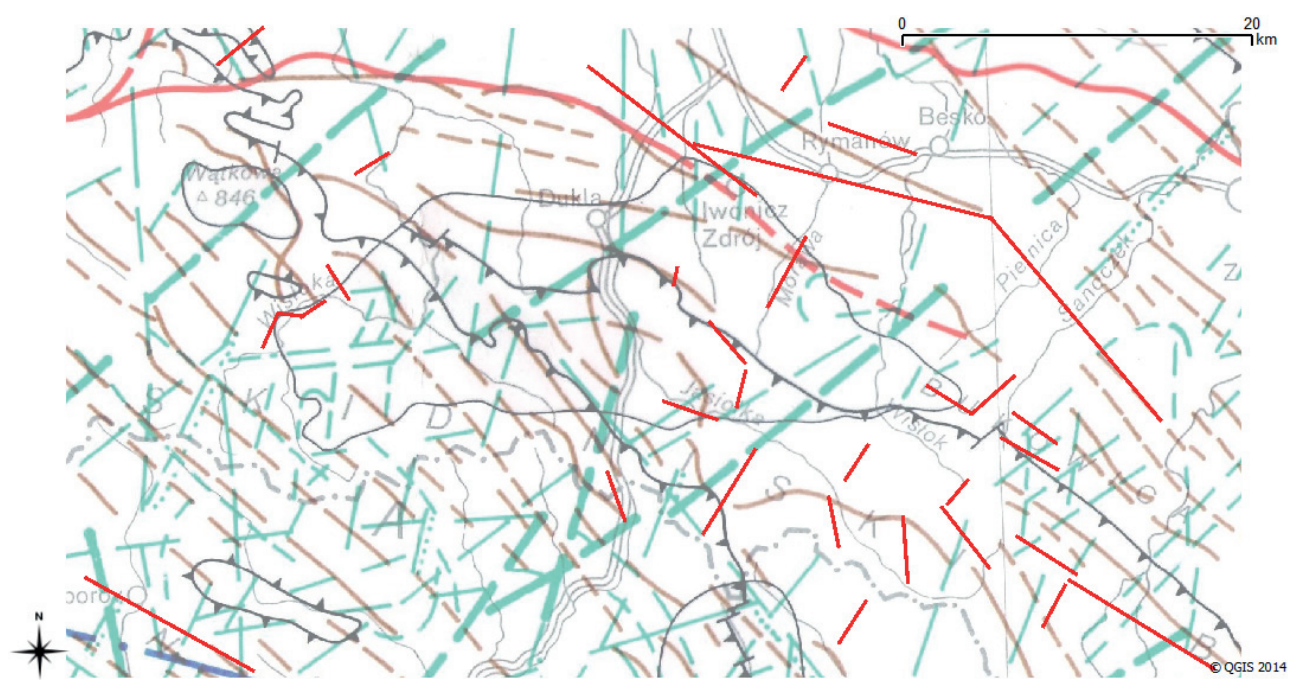

Fig. 5. New lineaments determined in the work (red colour), on the photolineaments map of Poland from 1988 (blue and brown colour)

During the analysis of this type of situation (Tab. 3), it was confirmed that some of the lineaments provide the basis for geological surveys in the scope of the interpreted area. Figure 6 presents examples of the previously unknown lineaments which, according to current knowledge, do not correspond with geological structures. They may, however, prove faults, as they can be found in the discontinuity zone. 
Table 3. New structures or interpretation errors

\begin{tabular}{||c|l|c|c|c||}
\hline No. & \multicolumn{1}{|c|}{ Dataset } & $\begin{array}{c}\text { Not reflected in the } \\
\text { geological structure }\end{array}$ & $\begin{array}{c}\text { Anthropogenic } \\
\text { character }\end{array}$ & $\begin{array}{c}\text { New structures or } \\
\text { interpretation errors }\end{array}$ \\
\hline \hline 1 & Inter-channel weighting & 24 & 8 & 17 \\
\hline 2 & KB 234 & 23 & 9 & 14 \\
\hline 3 & KB 247 & 16 & 8 & 8 \\
\hline 5 & KB 123 & 20 & 6 & 14 \\
\hline 4 & Quantization & 9 & 6 & 13 \\
\hline 6 & PAN image & 16 & 3 & 11 \\
\hline 7 & Thresholds & 12 & 3 & 1 \\
\hline 8 & Sobel's filter & 4 & 3 & 3 \\
\hline 9 & Thermal channel & 4 & 1 & \\
\hline
\end{tabular}
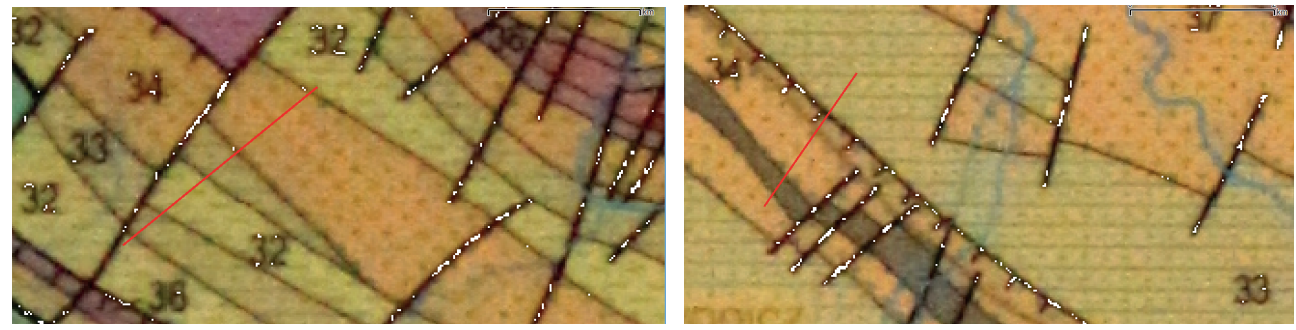

Fig. 6. Probable faults which were drawn in the process of photointerpretation (red colour) on the geological map

\section{Conclusions}

The results of the visual interpretation are characterized by a vast subjectivity. In the case of geological surveys, there is a difficulty related to the need of detection and description of phenomena which occur below the surface of the earth. The role of the researcher-interpreter is to detect geological features which can be found on the surface area by the exclusion of masking or misleading topographic elements, mainly the effects of human activities, but also the plant cover. Long-term experience proved that it may be effectively implemented in the case of searching for information in the tectonic character of the lineaments.

These surveys confirmed the suitability of satellite materials and visual processing methods in order to determine lineaments. The results were characterized by a higher number of linear assignations of this type than in current studies. Incorrect assignations were properly eliminated based on additional materials. It is worth 
noting that the determined lineaments which are not reflected on the geological maps do not have to be incorrect. The structure of the Carpathians, including the Low Beskids, is extremely complicated and geological knowledge of the area is incomplete. Linear image features which are not of anthropogenic character will find confirmation in elements of geological structure.

Partial evaluation and comparisons made it possible to realise the basic purpose of research, i.e. the alignment of individual image processing methods, in terms of their suitability for lineament detection. For the purpose of comprehensive validation, the use of quantitative and qualitative indicators, based on the detected number of linear elements and the balance between correctly and incorrectly identified geological linear structures was proposed. The coloured composition generation using inter-channel weighting was assumed as the best method of material preparation for B: 2/4, G: 2/5, R: 3/5 respectively. The highest number of assignations obtained in this way was confirmed by their high credibility on existing geological maps. The analysis proved that each of the methods brings new assignations to the general results. In order to determine the greatest number of lineaments, it is necessary to use different materials in total. The analysis of both results in quantitative and qualitative terms as well as the mutual repetition of results from different methods - it is recommended to use inter-channel weighting in the case of geological interpretation and additionally the KB 247 and quantization results of the close infrared image. The two recommended methods make it possible to effectively detect even small lineaments, which are the reflection of small forms and geological structures. The quantization results in additional linear features of great length which illustrates clear boundaries of geological zones and large faults. It enables us to link, in some cases, short lineaments which are determined through the use of other methods and drawn in the greater one.

The present paper should be treated as the first stage of the survey. In subsequent works it is planned to: use the new possibilities of Landsat 8 images (greater radiometric resolution of data, additional bands as compared to the previous missions, the possibility to integrate an panchromatic image with spectral channels), survey other possibilities of visual processing (PCA transformation, de-correlation strengthening of the coloured compositions), as well as to analyze the effectiveness of automatic action algorithms for determining the lineaments, comparing them with the results of completed photointerpretation analyses and available geological knowledge.

The dynamic of remote-sensing methods development and methods of computer images processing make it possible to presume that the meaning of photointerpretation analyses will increase and will compliment conventional geological methods. In this context, answers on the best selection, as well as complementary image data processing, seem crucial in order to achieve optimal results. 


\section{References}

[1] Bandat F.: Aerogeology. Gulf Publishing Company, Houston, Texas 1962.

[2] Bażyński J., Doktór S., Graniczny M.: Mapa fotogeologiczna Polski w skali 1:1 000 000. Wydawnictwa Geologiczne, Warszawa 1984.

[3] Bażyński J., Graniczny M., Oberc J., Wilczyński M.: Mapa fotogeologiczna Sudetów 1:200 000. Państwowy Instytut Geologiczny, Warszawa 1986.

[4] Chodyń R.: Zastosowanie cyfrowego modelu terenu (DEM) w badaniach geologicznych na przykładzie obszaru między Dobczycami a Mszana Dolna. Przegląd Geologiczny, vol. 52, nr 4, 2004, pp. 315-315.

[5] Ciołkosz A., Miszalski J., Olędzki J.R.: Interpretacja zdjęć lotniczych. WN PWN, Warszawa 1999.

[6] Dadlez R., Jaroszewski W.: Tektonika. WN PWN, Warszawa 1994.

[7] Davis J.C.: Statistic and Data Analyses in Geology. Willey, USA, Kansas 2002.

[8] Doktor S., Graniczny M.: Mapa głównych fotolineamentów Polski. PIG, Warszawa 1993.

[9] Graniczny M.: Fotolineamenty i ich znaczenie geologiczne. Instrukcje i Metody Badań Geologicznych 50, Wydawnictwa Geologiczne, Warszawa 1989.

[10] Graniczny M.: Kartowanie geologiczne z wykorzystaniem zdjęć satelitarnych Landsat. Biuletyn Państwowego Instytutu Geologicznego, nr 402, 2002, pp. 27-50.

[11] Graniczny M., Mizerski W.: Lineamenty na zdjęciach satelitarnych Polski-próba podsumowania. Przegląd Geologiczny, vol. 51, nr 6, 2003, pp. 474-482.

[12] Graniczny M., Mizerski W., Piątkowska A.: Lineaments Interpreted at the Radar Images and the Digital Elevation Model within the Palaeozoic Rocks of the Holy Cross Mts. Przegląd Geologiczny, vol. 53, nr 10/2, 2005, pp. 949-955.

[13] Hobbs W.H.: Lineaments of the Atlantic Border Region. Geological Society of America, vol. 15, no. 1, 1904, pp. 483-506.

[14] Jankowski L., Kopciowski R., Ryłko W.: Geological Map of the Outer Carpathians: Borderlands of Poland, Ukraine and Slovakia. PIG, Warszawa 2004.

[15] Jaroszewski W., Piątkowska A.: O naturze niektórych lineamentów. Annales Societalis Geologorum Poloniae, vol. 58, 1988, pp. 423-443.

[16] Kac J.G., Polatajew A.J., Rumiancewa E.F.: Osnowy lieamentnoj tektoniki. Niedra, Moskwa 1986.

[17] Kopciowski R.: Szczegółowa Mapa Geologiczna Polski w skali 1: 50 000, arkusz Zborów. Wydawnictwa Geologiczne, Warszawa 1999.

[18] Koszarski L. (ed.): Carpatho-Balcan Geological Association XIII Congress, Cracow, Poland 1985, Geology of the Middle Carpathians and the Carpathian foredeep: guide to excursion 3. Wydawnictwa Geologiczne, Warszawa 1985.

[19] Motyl-Rączkowska J., Ślączka A.: Ważniejsze lineamenty Karpat i ich zwiazek ze znanymi uskokami. Przegląd Geologiczny, vol. 32, nr 2, 1984, pp. 72-77. 
[20] O'Leary D.W, Friedman J.D, Pohn H.A.: Lineament, Linear, Lineation: Some Proposed New Standards for Old Terms. Geological Society of America Bulletin, vol. 87, 1976, pp. 1463-1469.

[21] Olędzki J.R.: Regiony fotomorficzne Polski. Akapit-DTP, Warszawa 2001.

[22] Ostaficzuk S.: Fotogeologia, fotointerpretacja i fotogrametria geologiczna. Wydawnictwa Geologiczne, Warszawa 1978.

[23] Ostaficzuk S.: Lineamenty jako odwzorowanie zjawisk tektonicznych na tle wybranych przykładów w Polsce. Biuletyn Geologiczny Uniwersytetu Warszawskiego 29, 1981, pp. 195-267.

[24] Sonder R.A.: Die Lineamenttektonik und ihre Probleme. Eclogae Geologicae Helvetiae, vol. 31, issue 1, 1938, pp. 199-238.

[25] Stelmaszczuk M., Wołk-Musiał E.: Metodyka przetwarzania oraz ocena przydatności zdjęć termalnych wykonanych przez satelitę Landsat w badaniach geologicznych. Teledetekcja Środowiska, t. 39, 2008, pp. 38-48.

[26] Szczęsny R.: Geologiczna interpretacja wybranego lineamentu z Podhala. Biuletyn Geologiczny Uniwersytetu Warszawskiego 31, 1987, pp. 401-410.

[27] Zvâgel'skij A.A.: Metodyka fotointerpretacji geologicznej. Wydawnictwa Geologiczne, Warszawa vol. 83, 1978. 